\title{
KEY AUDIT MATTERS PRACTICES IN CONSTRUCTION SECTOR: EVIDENCE OF MALAYSIAN MARKET
}

\author{
UMMI JUNAIDDA HASHIM ${ }^{1}$, NORSIAH AHMAD ${ }^{1}$, WAN AMALINA WAN ABDULLAH ${ }^{1}$, \\ ZALAILAH SALLEH ${ }^{2}$ \\ ${ }^{I}$ Authors are accounting lecturer at University Sultan Zainal Abidin, Malaysia, \\ ${ }^{2}$ Author an accounting lecturer at University Malaysia Terengganu, Malaysia;
}

junaidda@unisza.edu.my,norsiah@unisza.edu.my,amalina@unisza.edu.my,zalailah@umt.edu.my

\begin{abstract}
This paper examines the reporting of Key Audit Matters (KAMs) in independent auditor's report for construction sector in the Malaysian market. It also aims to identify whether the specific characteristics of construction company will influence the KAMs reporting for Malaysian companies. The sample covers all construction companies listed on Bursa Malaysia with available data one year upon the implementation of KAMs. This business sector has been the subject of the study due to the fact that construction sector, despite being a high-risk sector, is among important sectors that contribute to the development of the economy of a country. The objective of the study is achieved through content analysis. The maximum and minimum number of KAMs disclosed are six and one respectively for this sector. The main issue addressed as KAMs in construction sector is revenue. The revenue recognition in the construction sector is affected by the unexpected occurrences and this, in turn, will affect the estimated cost and profit. The findings discover that the practice on the KAMs disclosed has been critically assessed by the auditors, but there is exception on some of the practice. In the construction sector, the items listed as KAMs basically relates to areas that required a significant amount of judgement from auditors (matters that involve high uncertainty estimation). However, for some of the KAMs disclosure, $24 \%$ of the sample do not highlight the reason of why the items listed as KAMs. This circumstance would provide questions whether auditors had dismissed the guidelines of the disclosure of KAMs or auditors did not understand the KAMs' practices comprehensively. Therefore, further monitoring is needed to ensure the successful implementation of KAMs. This study only covers a limited sample of one year upon implementation of KAMs. It provides an empirical data and description on Key audit matters (KAMs) disclosure in the independent auditor's report of the Malaysian Listed company.
\end{abstract}

Keywords. Key audit matters (KAMs), New audit report, construction

\section{INTRODUCTION}

Stakeholders of companies rely on audited financial statements as guidance of their decisions towards the companies. For existing shareholders, the information would assist them either to retain as the shareholders or to become new investors of another company. Audited financial statements prepared by independent auditors comply with the regulated accounting standards of the market. The findings of the engagement will provide the true and fair situation of the companies especially on the financial health. However, the findings of the engagement shared by the auditor is limited to an opinion paragraph only. Accordingly, existing audit practices offer less informative disclosure to investors. It is observed that the transparency and integrity level is low in auditing practice. Therefore, the additional disclosure in the independent auditor's report is important to enhance the communicative value of the report (FocusM, 2016).

The new requirement on auditors' report of is stated in International Standard Auditing 701, Communicating of the Key Audit Matters and the standard has been released by the International Auditing and Assurance Standards Board (IAASB) during the year 2015. The ISA 701 is mandatory to all 
listed companies starting from 15 December 2016 onwards. The KAMs is reporting the most significant matters for the current period based on the auditor judgement.

Hence, this article particularly examines the reporting of KAMs in the independent auditor's report for construction sector in Malaysian market. Generally, the objective of the current study is to identify the extent of KAMs disclosure in the Malaysian market in the first year of implementation of the standard. There is only a few of literature in this area of study and none focusing on the construction sector. In addition, this study also will identify any impact of the construction sector on the KAMs disclosure. Content analysis has been conducted to achieve the objective of the study.

\section{LITERATURE REVIEW}

Why this industry has been chosen? Construction sector is one of the sectors that always suffer on financial issues either in local or global market. For example, in the Malaysian market, big construction companies always manage to obtain government "injection" in ensuring its continuity in operation due to the importance of the construction sector to the economy. The injection is in the form of new projects by government. The government itself is one of the biggest client in the industry. Literature also stresses that the construction sector has power to influence the overall economy condition of a country. Therefore, further attention to the sector is important to ensure its continuity to accelerate the countries' growth.

\subsection{Issues in the Construction sector}

The conceptual framework for financial reporting provides that the primary objective of the financial reporting is to provide decision useful information to all existing or potential stakeholders (International Accounting Standards Board, 2018). Particularly, the stakeholders will focus on the profit earned for the year when deciding whether or not to invest- in the company. The profit is produced from revenue earned during the year and deducted over the expenses incurred for the year. Few issues have been identified related to this sector including revenue recognition, construction delay and financial problems which are interconnected to one another. The first issue on revenue recognition has discussed follows.

Revenue is one of the most important part to measure financial performance of companies (Wagenhofer, 2014). The survey conducted by Graham, Harvey, and Rajgopal, (2005) reveal that financial executives officers have ranked revenue as more important than cash flow to the stakeholders. Therefore, the determination and reporting of revenue should be correct and reflects the actual condition of the company. In a construction company, determining revenue is an important part since it involves estimation and judgement of the management on the percentage of completion and cost incurred.

Determination of revenue in the construction company is one of the toughest part to the management. They are required to make an estimation in percentage based on work completed. The estimation could be either over or under estimated. The under estimation of cost would impact to the over declaration of profit for the current year. If the over declared revenue occurs, it would be an unavoided problem that need to be catered by the management. In a construction project, the efficiency of the project management would impact the four items including cost, time, quality and profit (Al-rubaiei, Abdul Nifa, $\&$ Musa, 2018). These four aspects are interrelated to one another in influencing the successfulness and profitability of the company. However, not all of the companies manage to apply and monitor the four mentioned aspects in their construction process.

Accordingly, the construction sector has been identified as the sample for this study due to the fact that this sector is among the important sectors that contribute in developing the economy of a nation. This sector has the power to generate wealth, improve the quality of living and hence, impose the booster effect to the other sector. This sector can be characterized as a unique sector whereby it involves extraordinary specialist, professions, variety of suppliers and applies construction technology to enhance profit and to be competitive with global market (Ramli et al., 2018). However, in Malaysia, this sector has been lagging behind as compared to other sectors. 
Nevertheless, construction sector has always being criticized due to various factors either during or after the project had been completed. The second issue is on the delayed or abandoned project. This situation occurs due to various factors and it indicates the seriousness of the problem that would impact the financial health of the company. The delay of the project is sometimes due to the variation orders, rework and destruction (Oyewobi, Jimoh, Ganiyu, \& Shittu, 2016). Riazi, Seng, Said, Mohd Nawi, \& Ismail, (2018) identify that the labour productivity issues in Malaysian market had caused lack of efficiency on the project that need for a revolution in construction process. These are among the factors that avoid of the zero-delay achievement.

The third issue is on delay which is also a crucial issue in construction sector as it would increase the cost and overhead of a company. Hamzah, Chen, Takim, \& Wong (2011) provide another view that the financial problems are among the determinant factors of the project delay. The fourth issue is on financial problem which is an interrelated issue as the payment pending has rooted to the cash flow matters, and subsequently the cash flow problems would be a constraint on getting a loan for continuing with another projects. Market factors such as high interest rate and inflation also deteriorate the abovementioned circumstance. These factors finally would influence the revenue recognition process.

Accordingly, the current study will examine the KAMs disclosed in the independent auditor's report and also to identify whether the critical- highlighted factors would be included in the primary issues highlighted in the KAMs disclosure.

\subsection{The reporting of KAMs}

Independent auditor's report is an important part of disclosure in an annual report of a company. However, the report have been presenting common information over the years and hence, less informative. The users themselves have demanded an informative independent auditor's report rather than providing an opinion paragraph only. In an effort to satisfy the users that demand on more informative audit report (Mock, Bédard, Coram, Espahbodi, \& Warne, 2013), the reform on auditor's report has been done after the years of discussion by the IAASB and other regulators. The process of reforming independent auditor's report includes introducing a new standard, ISA 701 Communicating Key Audit Matters (ISA 701) in the Independent Auditor's Report. The reporting of KAMs in the independent auditor's report is mandatory for all listed companies starting from 15 December 2016. The survey conducted by Carcello (2012) reveals that the professional users of financial statements request on having more disclosure by auditors which highlights the significant matters of the financial statements and audit risks.

ISA 701 was released by the IAASB in January 2015 and Malaysia Institute of Accountant (MIA) has approved the standard in April 2015. The standard has defined KAMs as any matters, based on auditor's judgment, are that most significant matters in the audit financial statements for the current period and the matters are among matters that have been communicated with those charge with governance of the company.

In addressing the KAMs, there are items that needs to be considered by auditors as follows;

1. Auditors need to assess the area that higher risk of material misstatement

2. Assessment need to carried out on the areas that required the significant judgement of auditor for the matters that involve high uncertainty estimation.

3. Auditor need to consider the effect on the audit of significant events or transactions that occurred during the period.

The identifying on the significance matters for the current period imposed a risk-based that need further recognising process including of assessing on the matters that has higher risk of material misstatement, designing and performing audit procedures responsive to those risks and obtain sufficient 
and appropriate audit evidence. The KAMs also would come from the matters that impose challenges to auditor in collecting the audit evidence.

The standard also provides that the significant matters would arise from the complex matters that need auditor judgement and this would reflect the audit strategy or further necessary involvement of senior personnel to resolve those issues. The communicating of KAMs require to have a separate paragraph in the independent auditor's report and the lengthy of the paragraph would depend on the auditor's judgement in effort to assist users to understand on the matters that most significance for the current period.

Paragraph 13 of the standard highlights that the communicating of KAMs must address the reason of why the item has been choose as KAMs and also the description on how the auditor address the issue. As the disclosure of KAMs is importance to users, the standard also required the auditor to provide reference on the related disclosure as part of the evidence of KAMs items. This is because, it would assist them in understanding the issue of KAMs arose in their investing companies. Diagram one provides the simplify stages in determining the KAMs.

The reporting of KAMs is supporting the communication theory whereby communication is achieved when it communicates adequate information. Therefore, KAMs will enhances the content of independent auditor's report and enable users do their best decision on their investment (Hashim, Ahmad, \& Salleh, 2018).

Diagram 1: Stages in identifying KAMs

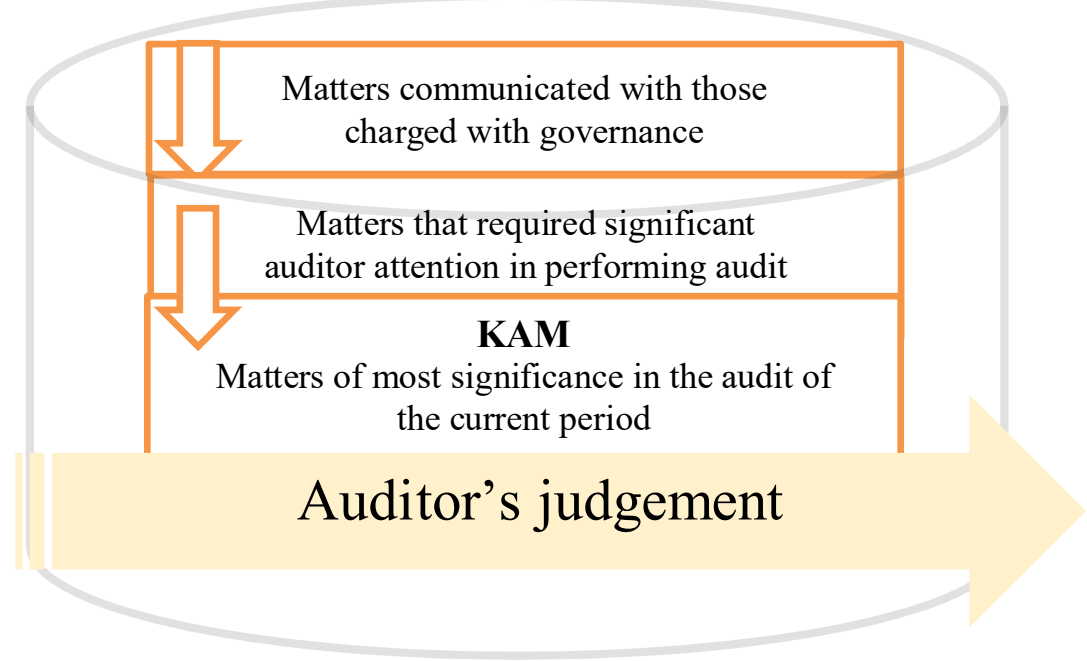

Sources, Determining and Communicating Key Audit Matters (“KAMs”)IASB June 2016

Clear, transparent reporting: The new auditor's report (Deloitte, 2016)

\section{METHODOLOGY}

For the current study, all samples of the construction companies listed at the main market of Bursa Malaysia will be choose. The total of construction companies is 48 while the final sample 46 due to the unavailable of the annual report of the companies. All of the final sample of the companies are satisfied and excluded from filter characteristics of Paragraph five, ISA 701 whereby when a company received the disclaimer opinion, the auditor is prohibited from issuing the KAMs (IAASB, 2015).

In achieving the objective of this study, a comprehensive review on the KAMs disclosed in the independent auditors' report has been done by the content analysis. Content analysis is a powerful method 
in research as it has noted the meaning seriously and it has been used widely in all area such as public opinion research, market research, political issue and on other emerging issues (Krippendorff, 2004). This study will identify on the number of KAMs disclosed and determine it fall under which category as illustrates in discussion part.

\section{THE PRACTICES AND DISCUSSIONS}

The following discussions provides the KAMs practices for construction sector for the year one.

\subsection{Simple descriptive analysis}

The descriptive analysis as table one shows that average/mean on of the KAMs disclosure in construction sector is 2.87 and this is no difference with (Bédard, Gonthier-besacier, \& Schatt, 2014) whereby the mean of the KAMs is 2.5. however, dissimilar to (Morais \& Pinto, 2017) provides the mean of KAMs for 3.84. With regards to the maximum number of KAMs disclosed, the other study of KAMs in European countries Morais \& Pinto (2017) reported the maximum number of KAMs is nine which is relatively difference on KAMs reported in the current study with six items only. In contrast to the minimum number of KAMs, the current study finds that one KAMs has been reported while (Morais \& Pinto, 2017) has reported zero KAMs for the minimum.

The results of this study are partly similar to (Bédard et al., 2014) for France market and it relatively difference with (Morais \& Pinto, 2017) for the European market. However, this could be difference if it covers the study of KAMs in other sector of companies.

Table 1. Descriptive Statistics for KAMs $(\mathrm{N}=46)$

\begin{tabular}{lccccccc}
\hline & & & & & & & \\
& & & Minimum & Maximum & Mean & Median & Mode \\
\hline Year one & KAMs & 46 & 1 & 6 & 2.87 & 2.5 & 2 \\
\hline
\end{tabular}

The frequency on number of the items disclosed is as shown in table two below. Mostly, $41 \%$ of the samples has reported with two items of KAMs in the independent auditor's report and then follows with three items of KAMs on $23 \%$ of the samples. Another frequent on the disclosure is $13 \%$ of the samples with five items disclosed and about $9 \%$ of the sample with frequency of one item of KAMs. The $6.5 \%$ of the samples has disclosed with five items and six items of KAMs respectively.

Table 2. Frequency on numbers of Item KAMs Disclosed

\begin{tabular}{ccc}
\hline & $\begin{array}{c}\mathrm{N} \\
\text { (no of } \\
\text { companies) }\end{array}$ & Percentage (\%) \\
\hline Frequency of KAMs disclosure & & \\
\hline 2 items & 19 & 41.3 \\
\hline 3 items & 11 & 23.93 \\
\hline 4 items & 5 & 13.04 \\
\hline 1 item & 4 & 8.69 \\
\hline 5 items & 3 & 6.52 \\
\hline 6 items & 3 & 6.52 \\
\hline Total no of companies & & \\
\hline
\end{tabular}


The disclosure of KAMs for the construction sector in Malaysia is made up of twelve items as table three and the graph below. The items are including of impairment on assets (other than goodwill), tax, revenue recognition, fixed assets (mostly on carrying value/fair value/valuation/disposal), other income, impairment of goodwill, provisions, liability assessments, cost/charges, acquisition, going concern, receivables, inventory and others. Number of each items disclosed is shown in table four below.

Table 3. Number of KAMs disclosure for construction companies

\begin{tabular}{|l|l|c|c|}
\hline & Items of KAMs & No of items & $\%$ \\
\hline 1. & Assets mostly impairment/other than goodwill & 8 & 6.1 \\
\hline 2. & Revenue recognition & 49 & 37.1 \\
\hline 3. & Fixed assets (cv/fv/valuation/disposal) & 12 & 9.1 \\
\hline 4. & Other income & 1 & 0.8 \\
\hline 5. & Impairment of Goodwill & 9 & 6.8 \\
\hline 6. & Provisions & 6 & 4.5 \\
\hline 7. & Liability & 5 & 3.8 \\
\hline 8. & Cost/charges & 8 & 6.1 \\
\hline 9. & Receivables & 26 & 19.7 \\
\hline 10. & Inventory & 3 & 2.2 \\
\hline 11. & Others & 6 & 1.5 \\
\hline & Total & 132 & 100 \\
\hline
\end{tabular}

Graph on KAMs disclosure year 1

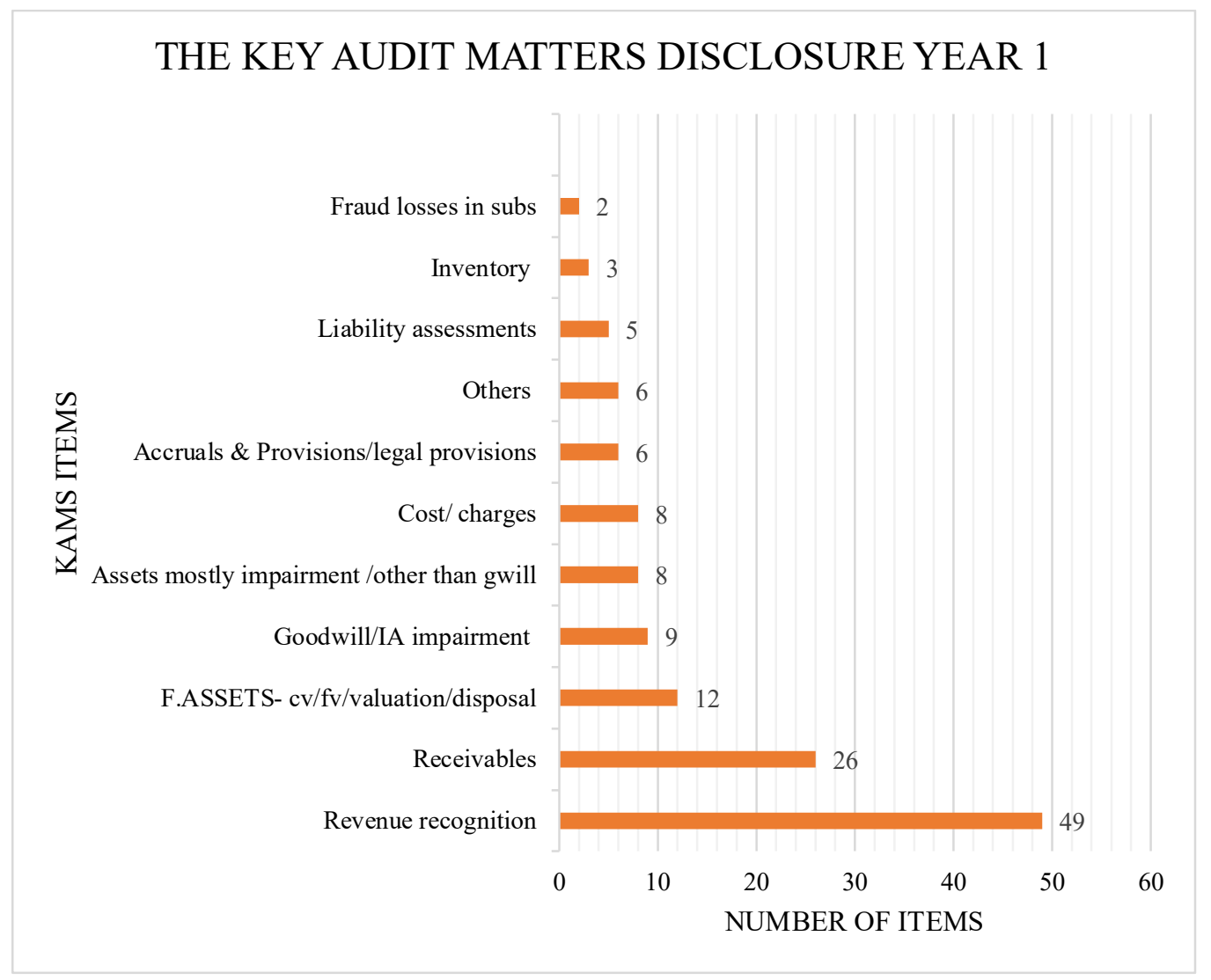


As highlighted in the standard, the reporting of KAMs are involving the items that mostly significant of the current period. The revenue recognition is among the items that has been identified as the important issues to be raised as the KAMs in construction sector with a total of 49 items. It is identified that there are few reasons of why are the revenue recognition has listed as KAMs in the disclosure. Firstly, the revenue for the construction company is derived from long term construction contracts which is spanned over more than one accounting period. Second, the construction project involves a huge amount which is obviously material to the company. Third, it required the judgement and estimation process that inherently complex in recognition of the revenue. Fourth, the significant judgement is exercised by management in determining the percentage of completion of the contract and estimates on the forecast costs of the contracts. Fifth, it would result in variance when the cost incurred difference with the estimations and this reflect the profit or loss in the current financial year. With that, revenue recognition is agreed as the material matters to be highlighted as KAMs by majority of the auditors in construction companies.

The other items that frequently disclosed as KAMs for the construction companies is receivables with total of 26. Mostly, the issues raised is on the recoverability of the account receivables. Identically, the matters of recoverability of the receivables are involve on management's judgement to indicate either the receivables amount would be impaired or not. It also includes on the monitoring and analyzing on the individual receivables accounts based on specific known facts or circumstances of the customer to assess either the customer has ability to settle their due amount or not. The analysis of the receivables accounts are including of trade receivables accounts, other receivables accounts and amount due from contract customer.

In summary, the details for the specific items that disclosed as KAMs has presented in the table four for year one in construction sector.

Table 4. General and Specific items of the KAMs disclosed

\begin{tabular}{|l|l|}
\hline Items of KAMs on: & Specific items of KAMs: \\
\hline Revenue recognition & \\
\hline \multirow{5}{*}{ Receivables } & Revenue Recognition on Construction Contract \\
\hline \multirow{5}{*}{ Fixed assets } & Recoverability of Other Receivables on arbitration award \\
\cline { 2 - 2 } & Settlement of amount due from a contract customer \\
\cline { 2 - 2 } & Recoverable on amount due from associates \& arbitration award \\
\cline { 2 - 2 } & Valuation of trade receivables \\
\cline { 2 - 2 } & Impairment loss of receivables \\
\cline { 2 - 2 } & Recoverability of amount due from related parties \\
\hline & \\
\hline \multirow{5}{*}{$\begin{array}{l}\text { Assets mostly impairment/exclude } \\
\text { goodwill }\end{array}$} & FV of Investment properties \\
\hline & Valuation of investment properties \\
\hline & Carrying amount of investment \\
\hline & Carrying Amount of Concession Right \\
\hline & The Carrying Value of Investment in Associate \\
\hline & Valuation of investment in an associate \\
\cline { 2 - 2 } & Fair Value of The Property, Plant and Equipment \\
\cline { 2 - 2 } & Impairment Assessment of Concession Assets \\
\cline { 2 - 2 } & Impairment of interest in a joint venture \\
\cline { 2 - 2 } & $\begin{array}{l}\text { Impairment assessment of the Group's and Company's investment in } \\
\text { joint venture }\end{array}$ \\
\cline { 2 - 2 } & Impairment assessment of service concession assets \\
\cline { 2 - 2 } & Impairment assessment of property, plant and equipment \\
\hline
\end{tabular}


OF MALAYSIAN MARKET

\begin{tabular}{|c|c|}
\hline & Impairment assessments of cost of investment in subsidiaries \\
\hline & Impairment assessment infrastructure development expenditure \\
\hline \multirow[t]{2}{*}{ Cost/charges } & Expenses recognition for construction business \\
\hline & Foreseeable loss on contract \\
\hline \multirow[t]{3}{*}{ Goodwill impairment/IA impairment } & Impairment of goodwill on consolidation \\
\hline & Annual impairment test of goodwill \\
\hline & Impairment assessment land rights \\
\hline \multirow[t]{4}{*}{ Provisions } & $\begin{array}{l}\text { Assessment of liquidated and ascertained damages ('LAD') on } \\
\text { supply and construction contracts }\end{array}$ \\
\hline & Contingent Liabilities - Major Litigations and Claims Reported \\
\hline & Crystallization of contingent liability \\
\hline & Outflow of resources on litigations and arbitrations. \\
\hline Liability & Amount due from customers \\
\hline \multirow[t]{4}{*}{ Inventory } & Valuation of inventory \\
\hline & Existence of inventory \\
\hline & Inventory valuation on unsold properties \\
\hline & The FV of the Inventories \\
\hline \multirow[t]{6}{*}{ Others } & Material Uncertainty on Going Concern \\
\hline & Purchase price on acquisition \\
\hline & Matters on group consolidation with foreign subsidiaries \\
\hline & Liquidity risk of the Group and the Company \\
\hline & Tax \\
\hline & Other income \\
\hline
\end{tabular}

Table 5. The auditors reason of choosing as KAMs

\begin{tabular}{|c|c|c|c|c|c|c|}
\hline \multicolumn{7}{|c|}{ Why choose as KAMs } \\
\hline & $\begin{array}{c}\text { Assess the area } \\
\text { that higher risk } \\
\text { of material } \\
\text { misstatement }\end{array}$ & $\begin{array}{l}\text { Assessment } \\
\text { the areas } \\
\text { required the } \\
\text { significant } \\
\text { judgement } \\
\text { of auditor } \\
\text { (matters that } \\
\text { involve high } \\
\text { uncertainty } \\
\text { estimation) }\end{array}$ & $\begin{array}{l}\text { Auditor need } \\
\text { to consider } \\
\text { the effect on } \\
\text { the audit of } \\
\text { significant } \\
\text { events or } \\
\text { transactions }\end{array}$ & $\begin{array}{c}\text { Materiality of } \\
\text { the } \\
\text { transactions }\end{array}$ & $\begin{array}{c}\text { Complexities } \\
\text { of the } \\
\text { transaction }\end{array}$ & $\begin{array}{l}\text { Highly } \\
\text { subjective } \\
\text { matters }\end{array}$ \\
\hline Frequency & 1 & 71 & 4 & 8 & 12 & 3 \\
\hline
\end{tabular}

Table 5 presents the auditors identified reason in rationalizing of KAMs disclosed in the independent auditor's report. Based on the review of the KAMs in the construction companies, the auditors identified that there are 71 of the KAMs items is due to the matters required significant judgement of the auditor and it involves high uncertainty estimation. Example of such justification has been extracted as follow; 
Revenue on construction contract contributed to $93 \%$ of the Group's total revenue.

The Group recognizes contract revenue and costs in profit or loss by using the percentage of completion method. The percentage of completion is determined by the proportion that contract costs incurred for work performed to date bear to the estimated total contract costs.

The revenue recognition on construction contract is considered to be a matter of significance as significant judgement is exercised in determining the percentage of completion, the extent of the costs incurred, the estimated total contract revenue and costs, as well as the recoverability of the contract projects.

The construction contract revenue and construction contract cost recognised in the profit or loss are disclosed in

Notes 4 and 5 to the financial statements respectively.

Annual report Ahmad Zaki Resources Berhad, 2016

The Group's Investment properties are carried at fair value. The Executive Directors engaged independent external values to determine the fair value of the investment properties every five years.

On an annual basis, the Executive Directors performed internal valuation based on actual transactions of similar type of properties and location.

We have identified the valuation of investment properties as a key audit matter because valuation included significant assumptions which are judgmental.

Annual report Ireka Corporation Berhad, 2017

\begin{abstract}
Financial impact of the in project in Abu Dhabi
The Group terminated its project in Abu Dhabi, United Arab Emirates, on 1 October 2015 and entered into an arbitration proceeding with the project owner. The arbitration commenced on 11 December 2015. As at 31 December 2016, the Group recorded a total receivable balance of AED207.7 million (RM253.7 million) due from the project owner in the consolidated statement of financial position.
\end{abstract}

The Directors are of the view that the Group has rightfully and validly terminated its employment under the contract with the project owner. The Directors have made an assessment and concluded that the total receivable balance is fully recoverable based on advice from the independent claim consultant and external solicitors.

The Group also has ongoing litigation and arbitration proceeding with its sub-contractors and a counter claim from the project owner arising from this project. The Directors have not provided for the claims made by the project owner as there is no sufficient evidence to support these claims based on the advice from the external solicitors.

This is a key audit matter due to the uncertainty relating to the outcome of the various arbitration proceedings in relation to this project.

Annual report Zelan Berhad, 2016

Besides that, the auditor also identified with 12 items of KAMs are due to the complexities of the transactions. However, in justifying the complexities of the transactions, it also depends on the auditor judgement either a transaction is a simple or complex. The extract of KAMs with such justification as follows:

Revenue recognition for construction contracts, due to the contracting nature of the business, involves significant judgments. This includes the determination of the total budgeted contract costs and the calculation of percentage of completion which affects the quantum of revenue to be recognised. In estimating the revenue to be recognised, the management considers past

experience and certification by customers and independent third parties, where applicable.

We determined this to be a key audit matter due to the complexity and judgmental nature of the budgeting of contract costs and the determination of revenue recognised.

Annual report Gadang Holdings Berhad, 2017 
Level of the materiality of the transactions are also among the reason of an item to be identified as KAMs. The materiality is a concept that widely discuss in both, either in financial reporting or auditing. The ISA 320 provides the guidelines on how the auditor would handle the materiality level of the company. Example of the KAMs on such issue as follow:

As at the financial year end, the management had exercised judgement by performing recoverability assessment due to no repayment was forthcoming. The management, on ground of prudence, decided to impair the receivable; whilst exploring avenues to institute legal proceedings against Hong Kong Oriental Rich and Force Investment Co Ltd ("HKOR").

For the financial year ended 31 December 2016, the management had made an impairment loss of RM19,779,610 to profit or loss of the Group.

This area was considered to be one of most significance to our audit due to the substantial sum outstanding and the inability for the debtor to settle the debt according to the repayment

schedule agreed upon.

Annual report, Kumpulan Jetson Berhad, 2016

\section{THE SHORTFALLS OF THE KAMS PRACTICES IN THE FIRST YEAR}

As described previously, paragraph 13 of the ISA 701 has provided that the disclosure of the KAMs in the independent auditor's report must enclose with the reason of choosing as KAMs, the description and references. However, the analysis of the KAMs for the year one of practices has identified that 12 of the samples had not provide the reason of why the items has been chosen as the KAMs for the current period. Besides that, there are also four companies that has reported the KAMs without providing the references on the issues highlighted. With regards to the non-compliance with the guidance of the ISA 701, the users possibly would not able to understood the KAMs reported since it has not been addressed properly by the auditor. However, the weakness on the KAMs practices is occurred during the initial year of regulation. The disclosure practice is assured will be better and more informative for the consecutive years of practices. The bar chart below provides figures on the number of companies complying with the guidance on paragraph 13.

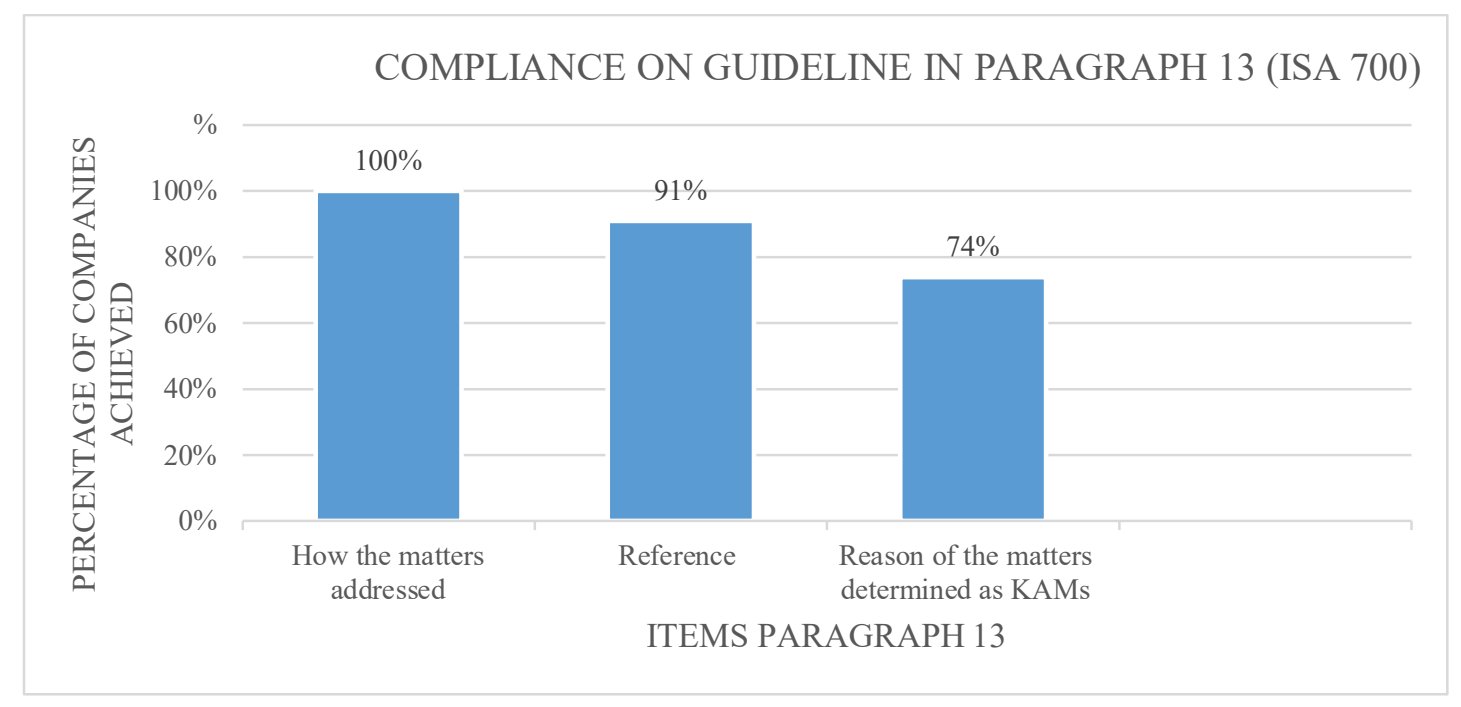

\section{CONCLUSION}

The reviewing of the KAMs disclosure in the independent auditor's report has enable to identify the best practice of the disclosure in the independent auditor's report. The best disclosure is not referred on the lengthy of the disclosure but based on ability of users to understood the issues highlighted. The practices of KAMs is strongly involve critical judgment and assessment of the auditor for the transaction, 
accounts and balances. The most frequent disclosure of KAMs for companies in construction is revenue recognition and this has been discussed extensively in previous section. The frequent on the trend of the KAMs disclosure would be found differently in another sector.

The KAMs disclosure is the independent auditor's report is in agree with the main issue of revenue that concern in the construction sector. Surprisingly, none of the company in the construction sector highlights on the issue of the construction delay and financial constraint as their KAMs. There are few factors that prohibit such matters to be communicated to their stakeholders. It is possibly that the matters would be sensitive, as sharing unfavorable information would be harmful to their audited company. Therefore, the information to the users is still limited and possibly the extent purpose of KAMs are not successfully achieved in this particularly sector. Hence, the communication theory in communication audit is still in constraint for the recent year. The limitation of the study is generalization cannot be made since this study offers an empirical data for the year one of KAMs only.

\section{REFERENCES}

[1] Al-rubaiei, Q. H. S., Abdul Nifa, F. A., \& Musa, S. (2018). PROJECT SCOPE MANAGEMENT EFFECT ON VARIATION ORDERS IN GOVERNMENT FUNDED PROJECTS : A PROPOSED STUDY ON THE. Malaysian Construction Research Journal, 3(1), 52-62.

[2] Bédard, J., Gonthier-besacier, N., \& Schatt, A. (2014). Costs and Benefits of Reporting Key Audit Matters in the Audit Report: The French Experience Costs and Benefits of Reporting Key Audit Matters in the Audit Report: The French Experience. Working Paper, (January), 1-24.

[3] Carcello, B. J. V. (2012). from the Standard Audit Report? The CPA Journal, (January 2012), 2012.

[4] Deloitte. (2016). Clear, transparent reporting: The new auditor's report. Retrieved from https:/www2.deloitte.com/content/dam/Deloitte/ch/Documents/audit/ch-en-audit-new-auditors-report.pdf

[5] FocusM. (2016). Revised audit standards a double-edged sword, 20-21.

[6] Graham, J. R., Harvey, C. R., \& Rajgopal, S. (2005). The economic implications of corporate financial reporting. Journal of Accounting and Economics, 40(1-3), 3-73. https://doi.org/10.1016/j.jacceco.2005.01.002

[7] Hamzah, A.-R., Chen, W., Takim, R., \& Wong, S. M. (2011). Project Schedule Influenced by Financial Issues : Evidence in Construction Industry. Scientific Research and Essay, 6(1), $205-212$. https://doi.org/10.5897/SRE10.989

[8] Hashim, U. J., Ahmad, N., \& Salleh, Z. (2018). Enhancing Investors Knowledge through the New Auditor's Report Requirement: The Underpinning Theories. International Journal of Academic Research in Business and Social Sciences, 8(December), 658-668. https://doi.org/10.6007/IJARBSS/v8-i12/5063

[9] IAASB. International Standards on Auditing 701: Communicating Key Audit Matters in the Independent Auditor's Report, 1 IFAC $\S(2015)$.

[10] International Accounting Standards Board. (2018). Conceptual Framework for Financial Reporting.

[11] Krippendorff, K. (2004). Content Analysis: An Introduction to Its Methodology. Education (Vol. 79). https://doi.org/10.2307/2288384

[12] Mock, T. J., Bédard, J., Coram, P., Espahbodi, R., \& Warne, R. C. (2013). Comment letter to respond to the IAASB invitation to comment on its Exposure Draft, Reporting on Audited Financial Statements : Proposed New and Revised International Standards on Auditing (ISAs ). 
[13] Morais, A. I., \& Pinto, I. (2017). Determinants of key audit matters disclosure : evidence from the UK, the Netherlands and France.

[14] Oyewobi, L. O., Jimoh, R., Ganiyu, B. O., \& Shittu, A. A. (2016). Analysis of causes and impact of variation order on educational building projects. Journal of Facilities Management, 14(2), 139-164. https://doi.org/10.1108/JFM-01-2015-0001

[15] Ramli, N. A., Abdullah, C. S., Mohd Nawi, M. N., Zalazilah, M. H., Mydin, M. A. O., \& Abd. Hamid, Z. (2018). A MODEL OF LOAD-BEARING MASONRY ( LBM ) TECHNOLOGY ADOPTION : EMPIRICAL STUDY IN. Malaysian Construction Research Journal, 3(1), 204-217.

[16] Riazi, S. R. M., Seng, L. Y., Said, I., Mohd Nawi, M. N., \& Ismail, R. (2018). THE USE OF SUPPLY CHAIN MANAGEMENT TO OVERCOME LOW LABOUR PRODUCTIVITY ISSUES IN THE TENTH MALAYSIA PLAN PUBLIC SECTOR. Malaysian Construction Research Journal, 3(1), 178-191.

[17] Wagenhofer, A. (2014). The role of revenue recognition in performance reporting. Accounting and Business Research, 44(4), 349-379. https://doi.org/10.1080/00014788.2014.897867 


\section{APPENDIX}

Sample of construction sector in Malaysian market

\begin{tabular}{|c|c|}
\hline 1. & Ahmad Zaki Resources Berhad \\
\hline 2. & Benalec Holdings Bhd \\
\hline 3. & Bina Puri Holdings Bhd \\
\hline 4. & Brem Holding Berhad \\
\hline 5. & Crest Builder Holdings Bhd \\
\hline 6. & DKLS Industries Bhd \\
\hline 7. & Econpile Holdings Bhd \\
\hline 8. & Ekovest Bhd \\
\hline 9. & Fajarbaru Builder Group Bhd \\
\hline 10. & Gadang Holdings Bhd \\
\hline 11. & Gamuda Bhd \\
\hline 12. & Gabungan AQRS Bhd \\
\hline 13. & George Kent (Malaysia) Bhd \\
\hline 14. & Ho Hup Construction Company Bhd \\
\hline 15. & Hock Seng Lee Bhd \\
\hline 16. & IJM Corporation Berhad \\
\hline 17. & Ikhmas Jaya Group Bhd \\
\hline 18. & Ireka Corporation Bhd \\
\hline 19. & JAKS Resources Bhd \\
\hline 20. & Kerjaya Prospek Group Bhd \\
\hline 21. & Kimlun Corporation Bhd \\
\hline 22. & Lebtech Bhd \\
\hline 23. & Melati Ehsan Holdings Bhd \\
\hline 24. & Mercury Industries Bhd \\
\hline 25. & Merge Energy Bhd \\
\hline 26. & MGB Bhd \\
\hline 27. & Mitrajaya Holdings Bhd \\
\hline 28. & MTD ACPI Engineering Bhd \\
\hline 29. & Mudajaya Group Bhd \\
\hline 30. & Muhibbah Engineering (M) Bhd \\
\hline 31. & OCR Group Bhd \\
\hline 32. & Pesona Metro Holdings Bhd \\
\hline 33. & Protasco Bhd \\
\hline 34. & Prinsiptek Corporation Bhd \\
\hline 35. & Pintaras Jaya Bhd \\
\hline 36. & Puncak Niaga Holdings Bhd \\
\hline 37. & Eversendai Corporation Bhd \\
\hline 38. & Sunway Construction Group Bhd \\
\hline 39. & Sycal Ventures Bhd \\
\hline 40. & TRC Synergy Bhd \\
\hline 41. & TSR Capital Bhd \\
\hline 42. & Vizione Holdings Bhd \\
\hline 43. & WCE Holdings Bhd \\
\hline
\end{tabular}

Received on February 1st, 2019 